\title{
Recombinant Bacillus subtilis strain deficient in production of surfactin loses ability to induce resistance of wheat plants against aphid Schizaphis graminum (Rond.)
}

Alekseev V.Yu., Veselova S.V., Blagova D.K., Sarvarova E.R., Burkhanova G.F., Rumyantsev S.D., Kasimova A.R., Maksimov I.V.

Institute of Biochemistry and Genetics, Ufa Federal Research Center of the Russian Academy of Sciences, Ufa, Russia E-mail: valentin-1994@yandex.ru

Key message. An important role of surfactin synthesis by endophytic bacteria in protecting wheat against cereal aphids has been shown to manifest itself in a direct insecticidal effect and an indirect effect through the induction of systemic resistance in plants.

Keywords: Bacillus subtilis 26D, surfactin, Schizaphis graminum, insecticidal activity, induced systemic resistance

The application of biological agents based on bacteria of the genus Bacillus is an effective way to increase the resistance of crops to aphids. Many members of the genus Bacillus can effectively inhibit the development of pests on plants due to various mechanisms, including the synthesis of peptide antibiotic substances - lipopeptides, which are involved in the relationship of bacteria with plants, phytopathogens, and pests. The aim of the research was to study the role of surfactin in protecting plants from cereal aphids. We used the bacterial strain Bacillus subtilis 26D, synthesizing surfactin and the recombinant line B. subtilis 26Dsfp , deficient in surfactin synthesis with knockout of the gene for surfactin synthetase ( $s f p$ ). We used methods for assessing pest survival and plant response to insect damage, real-time PCR, spectrophotometric methods for determining the concentration of reactive oxygen species (ROS) and the activity of pro / antioxidant enzymes. Unlike $B$. subtilis $26 \mathrm{D}$, the recombinant line of $B$. subtilis $26 \mathrm{Dsfp}{ }^{-}$did not directly insecticidal effect on the greenbug aphid $S$. graminum. In addition, $B$. subtilis $26 \mathrm{D}$ indirectly influenced the mortality of greenbug aphid fed on wheat plants treated with this strain. This strain increased pest mortality by a factor of three compared to untreated plants. Treatment of plants with the recombinant line $B$. subtilis 26Dsfp- did not affect mortality of greenbug aphids. With indirect (through the plant) effect on greenbug aphid $B$. subtilis 26D strain synthesizing surfactin increased the tolerance of wheat plants, and also induced systemic resistance, which was manifested in the accumulation of ROS, increased peroxidase activity and the accumulation of genes transcripts encoding protective proteins are markers of systemic resistance (PR-1, PR-2, PR-3, PR-6, PR-9 - pathogenesis-related protein). Treatment of plants with the recombinant line B. subtilis 26Dsfp did not increase the tolerance of plants and did not lead to the induction of systemic resistance, which was appeared in a decrease in the content of ROS and the absence of accumulation of transcripts of genes encoding protective proteins.

This work was supported by State Project no. 0246-2018-0035 and the RFBR project no. 17-29-08014.

\section{Рекомбинантный штамм Bacillus subtilis дефицитный по продукции сурфактина теряет способность индуцировать устойчивость растений пшеницы к злаковой тле Schizaphis graminum (Rond.) Алексеев В.Ю., Веселова С.В., Благова Д.К., Сарварова Е.Р., Бурханова Г.Ф., Румянщев С.Д., Касимова А.Р., Максимов И.В.}

Институт биохимии и генетики ФГБНУ Уфимского федерального исследовательского центра РАН, Уфа, Россия

\begin{abstract}
Аннотация. Показана важная роль синтеза эндофитными бактериями сурфактина в защите пшеницы от злаковой тли, проявлявшаяся в прямом инсектицидном эффекте и опосредованном эффекте через индукцию системной устойчивости в растениях.
\end{abstract}

Ключевые слова: Bacillus subtilis 26Д, сурфактин, Schizaphis graminum, инсектицидность, системная индуцированная устойчивость

Эффективным способом повышения устойчивости зерновых культур к тлям является применение биологических препаратов на основе бактерий рода Bacillus. Многие представители рода Bacillus могут эффективно сдерживать развитие вредителей на растениях за счет различных механизмов, в том числе за счет синтеза антибиотических веществ пептидной природы - липопептидов, вовлекающихся во взаимоотношения бактерий с растениями, фитопатогенами и насекомымивредителями. Цель работы состояла в изучении роли сурфактина в защите растений от злаковых тлей. В работе были использованы бактериальный штамм Bacillus subtilis 26Д, синтезирующий сурфактин и рекомбинантная линия B. subtilis $26 Д s f p$, дефицитная по синтезу сурфактина с подавленной активностью экспрессии гена сурфактинсинтетазы ( $s f p)$. В работе использованы методы оценки выживаемости вредителя и ответа растения на повреждение насекомыми, ПЦР в режиме реального времени, спектрофотометрические методы определения концентрации активных форм кислорода (АФК) и активности про-/антиокисдантных ферментов. В отличие от B. subtilis 26Д, рекомбинантная линия B. subtilis $26 Д s f p^{-}$не оказывала прямого инсектицидного эффекта на злаковую тлю S. graminum. Кроме того, B. subtilis 26Д опосредованно влиял на смертность злаковой тли, кормившейся на обработанных данным штаммом растениях пшеницы, увеличивая смертность вредителя в три раза по сравнению с необработанными растениями. Обработка растений рекомбинантной линией $B$. subtilis $26 Д s f p^{-}$не влияла на смертность злаковой тли. При опосредованном через растение воздействии штамм B. subtilis 26Д синтезирующий сурфактин повышал выносливость растений пшеницы, а также индуцировал системную устойчивость, что проявлялось в накоплении АФК, повышении активности пероксидаз и накоплении транскриптов генов, кодирующих защитные белки маркеры системной устойчивости (PR-1, PR-2, PR-3, PR-6, PR-9). Обработка растений рекомбинантной линией $B$. subtilis 26Дsfp - не повышала выносливость растений и не приводила к индукции системной устойчивости, что проявлялось в снижении содержания АФК и отсутствии накопления транскриптов генов, кодирующих защитные белки. Работа выполнена в рамках госзадания № 0246-2018-0035 и при финансовой поддержке РФФИ № 17-29-08014. 